DOI: 10.46340/eujem.2020.6.6.2

\author{
Andrii Kobernyk \\ ORCID ID: https://orcid.org/0000-0001-6642-5747 \\ National University of "Kyiv-Mohyla Academy», Ukraine
}

\title{
ENTREPRENEURIAL ECOSYSTEMS - PERSPECTIVES OF INNOVATIVE DEVELOPMENT
}

The article investigates the process of assessing the prospects and conditions for the formation of entrepreneurial ecosystems. The basis for the development of the appropriate assessment methodology was the study of foreign experience in the analyzed industry and its extrapolation to modern economic conditions in Ukraine. As a result, the author managed to formulate the main negative factors of entrepreneurial ecosystems development and to draft a methodology for their assessment, which is presented on numerical indicators. The article identifies factors (conditions) that contribute to the emergence of entrepreneurial ecosystems in the developed countries of the world, in particular in the US Silicon Valley; the analysis and prospects for the development of entrepreneurial ecosystems in Ukraine with these recommendations are formed. The author outlines the main stages of managerial decision-making in the development of entrepreneurial ecosystems depending on the development of the external environment and its own eco-orientation.

Key words: innovations, investments, ecosystem, entrepreneurial ecosystem, region, regional development.

Statement of the problem. The key factor determining the development and implementation of innovations are people, and in particular, their established interaction with each other. Cooperation of all participants of the innovation process is necessary because it forms a synergistic effect and growth of competitive advantages of both individual participants, their groups, and all innovative territorial formation. Similar synergy also accompanies the processes of production and economic activity greening: in the best ecological environment the quality of the population life increases, and accordingly grow their needs for the benefits generated by the production subsystem. Accordingly, there is a need to form and ensure the effective functioning of the entrepreneurial ecosystem, its innovative development. Assessment of such efficiency and innovation became the central element of the research. The object of research is entrepreneurial ecosystems of the developed countries of the world (on the example of the USA) as a scientific and practical basis for assessing the potential of Ukraine in creating their own entrepreneurial ecosystems (hereinafter EE). The subject of research is factors, models and processes of appearance and development of an entrepreneurial ecosystem. The author made an attempt to develop the fundamentals of methodological provisions for the assessment of entrepreneurial ecosystems using elements of EE concept developed by the author, consisting in the analysis of ecosystems, as well as the factors of EE emergence and development, which allows participants of the innovation process and its stakeholders to determine the attractiveness of the region for innovation and investment in its development, particularly in Ukraine.

Analysis of recent research and publications. Such foreign researchers as Bresky S., Carlson B., Lundwal B.A., Malerba F., Metkalf S., Stankevich R., Freeman K., Yakovleeva A. as well as domestic scientists - Yu.Bazhal, O.Humennna, O.Knut, O.Krasovskaya, S.Krechko, O.Kolomiets, O.Kurchenko, O.Marchenko, L.Fedulova, O.Yaremchuk devoted their research to methodological bases of national innovation systems. Prerequisites for the development of such ideas already existed and were illustrated in the works of M.Kolosovsky and A.Marshall, who investigated the principles of work, including environmental, agglomeration of companies within the regions; the development of the cluster concept itself is reflected in the papers of M.Porter, and then divided into studying the reasons for the formation of corresponding clusters (M.Weber, S.Cohen, P.Savitsky), as well as problems of internal factors of these clusters development (S.Valenta, A.Granberg, P.Krugman, S.Rosenfeld, M.Enright, etc.). However, within the framework of the theory of innovative ecosystems, the macro-level of innovation process organization 
with a focus on the state as a decision person is mainly considered. In this regard, there was a need to analyse the "horizontal" cut of such a system, the elements of which were separate companies and organizations.

The article is aimed at developing the foundations of methodological provisions for assessing the existing entrepreneurial ecosystems and determining the potential of Ukraine, taking into account the factors of development of EE.

The statement of the main material.The entrepreneurial ecosystem is seen by us as an integral part of functioning not only of an individual entity but also, basically, their synergistic associations. The main examples of such associations are specialized clusters that have been operating on the market for a long time, in particular Silicon Valley. In the analysis of existing Silicon Valley studies, a set of factors (conditions) contributing to the emergence of $\mathrm{EE}$ in the region was identified and systematized. With the help of the identified conditions, it is possible to estimate the degree of their presence in other regions of the world, which can serve as a reference point for different stakeholders to assess EE regions: to determine whether these conditions exist or they only need to be created (Table 1).

Table 1

Main and additional conditions for the occurrence of EE

\begin{tabular}{|c|c|}
\hline Main & Additional \\
\hline $\begin{array}{l}\text { The presence of the venture industry and main participants } \\
\text { of the ecosystem (universities, venture capitalists and highly } \\
\text { qualified labor force) }\end{array}$ & $\begin{array}{l}\text { Cultural aspects: } \\
\text { - cultural and national diversity; } \\
\text { - the opportunity to spend leisure time } \\
\text { in an interesting way; } \\
\text { - a liberal way of life; } \\
\text { - availability of communities }\end{array}$ \\
\hline The presence of a critical mass of talented people & Geographical position \\
\hline Availability of market demand (demand) & Climatic conditions \\
\hline $\begin{array}{l}\text { Legislation and taxation system favorable } \\
\text { for the business development }\end{array}$ & The presence of large corporations \\
\hline Presence of success stories (success stories) & High authority of the region \\
\hline $\begin{array}{l}\text { Cultural aspects: } \\
-\quad \text { a favorable business environment } \\
-\quad \text { calm attitude to failures } \\
-\quad \text { high status of technical specialists }\end{array}$ & $\begin{array}{l}\text { Freedom of entrepreneur's action in a combination } \\
\text { with limited financial support from the state }\end{array}$ \\
\hline Availability of small business support programs & \multirow{6}{*}{$\begin{array}{l}\text { Region's independent implementation of product } \\
\text { expertise functions }\end{array}$} \\
\hline Availability of infrastructure (material and human ones) & \\
\hline System of material incentives for the employees & \\
\hline time factor & \\
\hline The proximity of the investor and the object for investments & \\
\hline Concentration on the region's advantages & \\
\hline
\end{tabular}

\section{Source: Developed by Author on the basis of ${ }^{l}$}

To analyse the maturity of regions, we suggest applying the elements of hierarchies analysis methods, namely those that consist in the selecting and evaluating the importance of certain criteria, which most affect the results of the analysis and also the calculation of the integral indicator with the subsequent ranking of the obtained ratings. To do this, it is also necessary to apply the elements of expert assessments method, in particular, in establishing the weights (significance, weight coefficients) of the allocated factors (conditions) influencing the formation of EE. These coefficients will serve as an element of the methodology for determining the rating among the studied regions and clusters. To conduct the assessment, we suggest distinguishing the following quantitative and qualitative factors: the volume of venture capital in the region,

\footnotetext{
${ }^{1}$ Яковлева, А. Ю. (2012). Факторы и модели формирования и развития инновационных экосистем: диссертация на соискание научной степени кандидата экономических наук. Москва: Национальный исследовательский ун-т "Высшая школа экономики".
} 
the aggregate number of operating companies within the cluster (region), the range of their activities, that is, the coefficient of diversity. The weight criteria of these factors according to the widespread assessment (on the basis of expert opinions) are:

- volume of venture financing -0.521 ;

- number of cases (aggregated) on the date -0.38 ;

- coefficient of diversity $-0,099^{1}$

Having determined the main and additional conditions for the emergence of an entrepreneurial ecosystem, specifying their qualitative and quantitative characteristics and having established their weight coefficients, we can formulate an integral assessment of regions in the context of the prospects for innovative development of entrepreneurial ecosystems (Table.2).

Table 2

Calculation of the regions ranking for each indicator

\begin{tabular}{|c|c|c|c|c|}
\hline Municipal Statistical Areas (MSA) & $\begin{array}{l}\text { Venture capital } \\
\qquad(52.1 \%)\end{array}$ & $\begin{array}{c}\text { Number } \\
\text { of companies } \\
\text { aggregated } \\
\text { as of the date } 38.8 \%\end{array}$ & $\begin{array}{c}\text { Ratio } \\
\text { of diversity - } \\
9,9 \%\end{array}$ & $\begin{array}{l}\text { Integral } \\
\text { assessment } \\
\text { of regions }\end{array}$ \\
\hline San Francisco-Oakland-Fremont, CA & 0.273413 & 0.390538 & 0.025186 & 0.689137 \\
\hline $\begin{array}{l}\text { New York-Northern New Jersey-Long } \\
\text { Island, NY-NJ-PA }\end{array}$ & 0.14271 & 0.129568 & 0.039624 & 0.311902 \\
\hline San Jose-Sunnyvale-Santa Clara, CA & 0.11012 & 0.11578 & 0.034216 & 0.260116 \\
\hline Boston-Cambridge-Quincy, MA-NH & 0.119383 & 0.10359 & 0.041459 & 0.264432 \\
\hline $\begin{array}{l}\text { Los Angeles-Long Beach-Santa Ana, } \\
\text { CA }\end{array}$ & 0.082333 & 0.083174 & 0.035611 & 0.201118 \\
\hline Seattle-Tacoma-Bellevue, WA & 0.03259 & 0.02175 & 0.053903 & 0.108244 \\
\hline San Diego-Carlsbad-San Marcos, CA & 0.028473 & 0.02165 & 0.047313 & 0.097437 \\
\hline Chicago-Naperville-Joliet, IL-IN-WI & 0.027787 & 0.020487 & 0.048793 & 0.097068 \\
\hline $\begin{array}{l}\text { Washington-Arlington-Alexandria, DC- } \\
\text { VA-MD-WV }\end{array}$ & 0.031904 & 0.017148 & 0.06693 & 0.115982 \\
\hline Atlanta-Sandy Springs-Marietta, GA & 0.019897 & 0.015516 & 0.046131 & 0.081545 \\
\hline Austin-Round Rock, TX & 0.026758 & 0.013733 & 0.070093 & 0.110585 \\
\hline Denver-Aurora, $\mathrm{CO}$ & 0.014065 & 0.010027 & 0.050464 & 0.074556 \\
\hline $\begin{array}{l}\text { Philadelphia-Camden-Wilmington, PA- } \\
\text { NJ-DE-MD }\end{array}$ & 0.031904 & 0.009583 & 0.119773 & 0.16126 \\
\hline Baltimore-Towson, MD & 0.012693 & 0.00826 & 0.055281 & 0.076234 \\
\hline Provo-Orem, UT & 0.007204 & 0.008254 & 0.0314 & 0.046858 \\
\hline Santa Barbara-Santa Maria-Goleta, CA & 0.005832 & 0.008157 & 0.025722 & 0.03971 \\
\hline $\begin{array}{l}\text { Minneapolis-St. Paul-Bloomington, } \\
\text { MN-WI }\end{array}$ & 0.009605 & 0.006853 & 0.050421 & 0.06688 \\
\hline $\begin{array}{l}\text { Miami-Fort Lauderdale-Pompano } \\
\text { Beach, FL }\end{array}$ & 0.008919 & 0.005587 & 0.057431 & 0.071937 \\
\hline Durham, NC & 0.007204 & 0.005243 & 0.04943 & 0.061877 \\
\hline Salt Lake City, UT & 0.007204 & 0.0051 & 0.050819 & 0.063123 \\
\hline
\end{tabular}

Source: Developed by Author on the basis of ${ }^{2}$

The obtained results of the rating generally correspond to the popularity of municipal statistical areas, which is designated by investors. Based on the example of Silicon Valley, the analysis of main regions of Ukraine rating among the investment climate and innovation activity was carried out (Table. 3).

\footnotetext{
${ }^{1}$ Ibid.

${ }^{2}$ Compiled by the author on the basis of data from National Venture Capital Association. (2020). Homepage $<$ https://nvca.org/> (2020, July, 01).
} 
For the purposes of the analysis, the most economically developed and investment-attractive regions of Ukraine that can become cluster-forming regions have been chosen according to investors' estimates.

Table 3

The results of the integral assessment

\begin{tabular}{|l|c|c|c|c|c|}
\hline \multicolumn{1}{|c|}{ Regions } & $\begin{array}{c}\text { Venture capital } \\
(52.1 \%)\end{array}$ & $\begin{array}{c}\text { Number } \\
\text { of companies } \\
\text { aggregated as } \\
\text { of the date } \\
38.8 \%\end{array}$ & $\begin{array}{c}\text { Ratio of diversity - } \\
9,9 \%\end{array}$ & $\begin{array}{c}\text { Integral } \\
\text { assessment of } \\
\text { regions }\end{array}$ & Ranking \\
\hline Kyiv region & 0.598454 & 0.000875 & 0.197265 & 0.796594 & 1 \\
\hline Kharkiv region & 0.141403 & 0.000513 & 0.250199 & 0.392115 & 3 \\
\hline Lviv region & 0.105624 & 0.000229 & 0.260909 & 0.366762 & 4 \\
\hline Dnipro region & 0.154518 & 0.002642 & 0.291627 & 0.448787 & 2 \\
\hline
\end{tabular}

Source: Developed by Author on the basis of ${ }^{l}$

Based on the results of the indicators analysis and ranking of the integral index, it has been determined that Kyiv and Dnipro regions are the most promising for creating an entrepreneurial ecosystem. However, the above list of factors of an entrepreneurial ecosystem formation is not exhaustive, and even the indicators chosen for analysis are subject to constant influence of the external environment. Accordingly, we can distinguish and systematize the problems for the creation of entrepreneurial ecosystems in Ukraine (Table 4).

Table 4

Ukraine's problems in the creation of $\mathrm{EE}$

\begin{tabular}{|l|l|}
\hline \multicolumn{1}{|c|}{ At the level of power } & \multicolumn{1}{c|}{ At the level of science } \\
\hline $\begin{array}{l}\text { - Lack of a favorable climate for innovation } \\
\text { - Lack of innovative development programs } \\
\text { - Lack of effective management system } \\
\text { in the field of innovation }\end{array}$ & $\begin{array}{l}\text { Non-competitiveness of Ukrainian science } \\
\text { Problems with the commercialization of scientific research } \\
\text { and development results } \\
\text { Psychological barriers in involving the universities } \\
\text { into innovation activity }\end{array}$ \\
\hline \multicolumn{1}{|c|}{ At the business level } & \multicolumn{1}{|c|}{ At the level of infrastructure } \\
\hline $\begin{array}{l}\text { Unwillingness to invest in innovation } \\
\begin{array}{l}\text { Lack of developed business environment } \\
\text { young people of creative business culture among }\end{array}\end{array}$ & $\begin{array}{l}\text { Lack of an effective funding system } \\
\text { Absence of an extensive network of business incubators } \\
\text { Lack of economic incentives for distribution of clusters }\end{array}$ \\
\hline
\end{tabular}

Source: Developed by Author on the basis of

As noted by L. Fedulova: "For the regions of Ukraine, this should be a strategic direction of integration with the EU countries, which have practical experience in implementing regional policy based on the application of concepts of open innovation and regional innovation ecosystems" ${ }^{3}$. Agreeing with the above statement and supplementing it, it is worth noting that it is the creation of entrepreneurial ecosystems that can become a skeleton that will be the basis of not just industrial or investment clustering

\footnotetext{
${ }^{1}$ Державна служба статистики (2020). $R \& D$ costs are equated with venture capital investment <https://ukrstat.org/uk/operativ/operativ2013/fin/kp_reg/kp_reg_u/kp_reg_u_2015.htm> (2020, July, 01); Державна служба статистики (2020). Головна сторінка <http://www.ukrstat.gov.ua/> (2020, Липень, 01); Клиновий, Д. В., Пепа, Т. В. (2006). Розміщенняпродуктивних сил та регіональнаекономікаУкраїни. Київ: Центр навчальної літератури. $728 \mathrm{c.}$

${ }^{2}$ Сімпсон, О. (2016). Екосистемаінновацій, проблеми та перспективи в України. Slideshare.Net

<https://www.slideshare.net/Comedianua/ss-69317234/1>(2020, липень, 01).

${ }^{3}$ Федулова, Л. І. (2015). Концептуальні засади формування інноваційної екосистеми регіону.

Інновачійнаекономіка, 4, 153-158. <http://nbuv.gov.ua/UJRN/inek_2015_4_25.> (2020, липень, 01).
} 
of business, but that of eco-conscious management aimed at the prospects and innovativeness of development. To stimulate scientific, technical and innovation one should combine government regulation with respect to the interests of private business and the widespread use of market leverage redistribution of capital in priority areas and industries, as well as promoting positive structural changes in the economy and growth of social and private effects from the introduction of innovations ${ }^{1}$.

The process of building a cluster of eco-oriented enterprises covers not only direct producers of products, but also a whole complex of elements of the relevant infrastructure: social investors, intermediaries, educational institutions, business incubators, business associations, consortiums and holdings, trading network, research and innovation institutions, state supervision and support bodies, media, and of course, the community of a certain territory. The main outstanding feature of the cluster is territorial integrity, that is why entrepreneurial ecosystems in this sense should be created in a favourable external environment, with the support of local self-government bodies and the population. Nowadays, the basis for the formation of entrepreneurial ecosystems in Ukraine are public formations and institutions of social orientation. They are the main initiators and accelerators of eco-programs in entrepreneurship. Their functioning is supported by so-called donors: investors, which mainly include financial institutions and government and intergovernmental funds that can provide irrevocable financial assistance, specialized grants or funds in the form of payback investment.

Nowadays, interest in eco-oriented business is constantly growing and goes beyond the responsibility of the state. Programs of modern philanthropists in business development usually have an eco-component. Financial support for entrepreneurial ecosystems is mainly due to the implementation of technical assistance projects with the support of international donor organizations, but there are investment funds, venture philanthropists, private funds and regional state funds that contribute to the development of eco-oriented business. At the same time, very often financial support for environmental programs is formal or even declarative: assistance or investment is provided only in the form of starting capital or intangible form (information support, advertising, PR), and in the future the entrepreneur remains with his vision of the business itself. Loans for business development, especially for eco-technologies, remain inaccessible, there are no tax incentives and other ways to stimulate the development of entrepreneurial ecosystems. However, in some regions of Ukraine, in particular Chernivtsi, Rivne and Transcarpathian, local governments maximize their efforts to ensure a favourable environment for entrepreneurial ecosystems. Accordingly, the process of their formation depends entirely on the assessment of the state not only of the company's own potential, but also of the external environment.

Thus, we can formulate a schematic process of assessing regions in terms of establishing the prospects for the formation of an entrepreneurial ecosystem (Fig.1).

The suggested scheme reflects the stages and a set of sequential actions aimed at making a decision on the support or refusal towards EE. The first stage is to assess the maturity of the actual conditions for the emergence and development of EE, the level of which is determined by expert means. Basing on the expert assessment of conditions, the conditions matrix is formed, on the basis of which, the conclusion is made about the level of EE maturity. It should also be noted that from the existing conditions, for "from scratch" regions ${ }^{2}$ it is necessary to determine first whether there are "basic conditions of the 1st level" in the region, i.e. whether there are "universities", "venture capitalists" and "demand" in the region. At the second stage. The quantitative assessment of maturity consists of three stages:

- analysing the trend of the changes in the characteristic indicator, which is an indicator of the region's degree of diversity and potential; calculation of the integral indicator; - diagnostics of maturity.

The third stage is the decision-making process, from which it is concluded whether it makes sense to carry out a further assessment procedure or further study of the region is rejected (decay and stagnation).

At the fourth stage , an assessment of the period necessary for the studied region to achieve the target level of EE development according to its diversity coefficient is carried out.

The last, fifth stage, includes the decision-making process when the conclusion is made about the prospects of the region from the standpoint of development of innovation activity in it and the decision on its support is taken or rejected.

\footnotetext{
${ }^{1}$ Гаджієв, Б. Р., Прогулова, Т. Б., Гібіна, Е. Ю. (2010). Зростаючі мережі з комбінованими механізмами росту. Swsys. $R$ u <http://swsys.ru/index.php?page=article\&id=2572> (2020, липень, 01).

2 "with history" - where there is an opportunity to create an entrepreneurial ecosystem; "from scratch" - where there are no valid entrepreneurial ecosystems, but there are some opportunities to create them.
} 


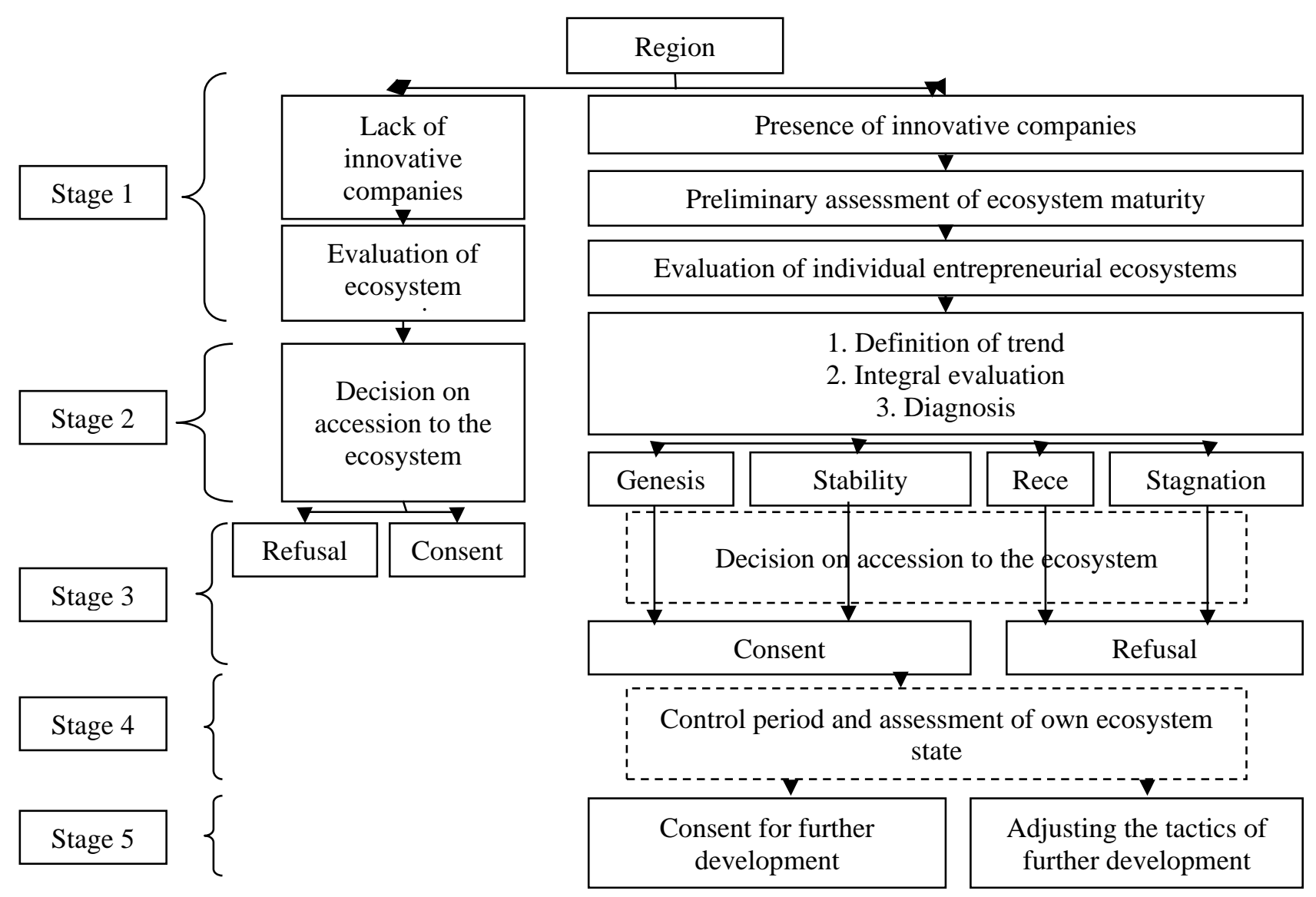

Fig. 1. Stages of regions assessments

\section{Source: Developed by Author on the basis of ${ }^{1}$}

The process of entrepreneurial ecosystems formation faces many difficulties that business is not able to directly influence. Among such obstacles is the low level of the information environment development, limited knowledge of eco-oriented enterprises about each other, lack of targeted communication and interaction between stakeholders. Therefore, local self-government bodies at the cluster level should create appropriate platforms: co-working, regular thematic seminars and conferences that can ensure effective exchange of experience between enterprises, dissemination of advanced technologies, place and way of expression of public opinion, become a platform for finding investors and creating investment eco projects, etc.

The main feature of entrepreneurial ecosystems is that in it the greening of business processes shifts the main goal of conducting economic activity - profit, that is, it becomes the main, equal, and not the accompanying one.

Conclusion. Formed classified factors (conditions) that contribute to the emergence and development of EE in the region, represent an assessment of the attractiveness and potential of the region. With the use of hierarchies elements analysis, an integral assessment of each studied region was calculated on the basis of a number of criteria (taking into account the coefficient of the diversity of companies' activities ) and further ranking of estimates. Combination of tools for assessing the stage of EE maturity and identifying the factors of EE development create prerequisites for developing the set of actions aimed at creating favourable conditions for innovation activities and ensuring the dynamics of EE development.

\footnotetext{
${ }^{1}$ Яковлева, А. Ю. (2012). Факторы и модели формирования и развития инновационных экосистем: диссертация на соискание научной степени кандидата экономических наук. Москва: Национальный исследовательский ун-т "Высшая школа экономики".
} 


\section{References:}

1. Yakovleva, A. Yu. (2012). Faktory i modeli formirovaniya i razvitiya innovatsionnykh ekosistem [Factors and models of formation and development of innovative ecosystems]: dissertatsiya na soiskaniye nauchnoy stepeni kandidata ekonomicheskikh nauk [dissertation for the degree of candidate of economic sciences]. Moscow: National Research University "Higher School of Economics". [in Russian].

2. National Venture Capital Association (2020). Homepage <https://nvca.org/> (2020, July, 01) [in English].

3. Derzhavna sluzhba statystyky [State Statistics Service]. (2020). Holovna storinka [Homepage] <http://www.ukrstat.gov.ua/> (2020, July, 01) [in Ukrainian].

4. Klynovyi, D. V., Pepa, T. V. (2006). Rozmishchennia produktyvnykh syl ta rehionalna ekonomika Ukrainy [Location of productive forces and regional economy of Ukraine]. Kyiv: Tsentr navchalnoi literatyry. [in Ukrainian].

5. Simpson, O. (2016). Ekosystema innovatsii, problemy ta perspektyvy v Ukrainy [Innovation ecosystem, problems and prospects in Ukraine] <https://www.slideshare.net/Comedianua/ss-69317234/1> (2020, July, 01) [in Ukrainian].

6. Fedulova, L. I. (2015). Kontseptualni zasady formuvannia innovatsiinoi ekosystemy rehionu [Conceptual bases of formation of innovative ecosystem of the region] Innovatsiina ekonomika [Innovative economy], 4, 153-158. <http://nbuv.gov.ua/UJRN/inek_2015_4_25> (2020, July, 01) [in Ukrainian].

7. Hadzhiiev, B. R., Prohulova, T. B., Hibina, E. Iu. (2010). Zrostaiuchi merezhi z kombinovanymy mekhanizmamy rostu [Growing hems with combined growth mechanisms] $<$ http://swsys.ru/index.php?page=article\&id=2572> (2020, July, 01) [in Ukrainian]. 